\title{
Parallel process evaluation using a proposed framework for the design and reporting of process evaluations for cluster-randomised trials of complex interventions
}

\author{
Aileen Grant ${ }^{1 *}$, Tobias Dreischulte ${ }^{2}$, Bruce Guthrie ${ }^{1}$ \\ From 2nd Clinical Trials Methodology Conference: Methodology Matters \\ Edinburgh, UK. 18-19 November 2013
}

Process evaluations are recommended to open the 'black box' of complex interventions evaluated in trials, but there is limited guidance to help with design, with most guidance focused on the use of qualitative methods rather than processes to evaluate. We have developed a framework that identifies a range of candidate processes that an evaluation could examine to understand clusterrandomised intervention implementation and maintenance. These include processes involving clusters (recruitment, delivery of the intervention to the cluster, adoption by the cluster), involving the individuals on whom outcomes are measured (reach, delivery of the intervention to the individual, response of the individual), maintenance, and unintended consequences. Researchers will often have to choose what to focus on because of resource constraints, the framework aims to help researchers make explicit their choices of research questions and methods.

We will illustrate application of the framework to the design and conduct of a parallel process evaluation of the Data-driven Quality Improvement in Primary Care trial, which evaluates a complex intervention to improve prescribing safety in 40 general practices. This mixed method process evaluation includes a dominant case study approach in a purposeful sample of practices and hypothesis-testing quantitative analysis of data from all practices examining how key processes are associated with variation in outcome between practices. We will present analysis of qualitative data from the 10 case study practices participating $(6$ reducing and 4 not

${ }^{1}$ University of Dundee, Dundee, UK

Full list of author information is available at the end of the article reducing targeted prescribing), and focus groups with patients who have had their medication changed as a result of the intervention.

\section{Authors' details}

${ }^{1}$ University of Dundee, Dundee, UK. ${ }^{2}$ NHS Tayside, Dundee, UK.

Published: 29 November 2013

doi:10.1186/1745-6215-14-S1-088

Cite this article as: Grant et al:: Parallel process evaluation using a proposed framework for the design and reporting of process

evaluations for cluster-randomised trials of complex interventions. Trials 2013 14(Suppl 1):O88.

Submit your next manuscript to BioMed Central and take full advantage of:

- Convenient online submission

- Thorough peer review

- No space constraints or color figure charges

- Immediate publication on acceptance

- Inclusion in PubMed, CAS, Scopus and Google Scholar

- Research which is freely available for redistribution 